\title{
ANALISIS NILAI TAMBAH PRODUK TURUNAN MADU PADA CV. MADU APIARI MUTIARA CIMANGGIS, DEPOK, JAWA BARAT
}

\author{
Fahmi Noval Amar, Eny Dwiningsih* dan Armaeni Dwi Humaerah
}

\begin{abstract}
ABSTRAK
Tujuan dari penelitian ini adalah: 1) untuk menentukan rasio nilai tambah, produktivitas, dan margin distribusi yang dihasilkan dari setiap produk yang berasal dari madu, dan 2) untuk menentukan efisiensi produk turunan madu selama periode analisis dari tahun 2012 sampai 2013. penelitian ini dilakukan di CV. Madu Apiari Mutiara terletak di Depok, Jawa Barat. Metode Hayami, rasio produktivitas dan rasio R / C yang digunakan untuk menganalisis data. Hasil dari analisis data menunjukkan bahwa nilai rata-rata tambah per produksi seluruh produk Rp 20.892,90, - atau dengan rata-rata nilai tambah rasio 35,65\%. Produk dengan produktivitas tertinggi adalah madu shampoo. Secara keseluruhan, nilai $\mathrm{R}$ / C sebesar 1,90 menunjukkan efisiensi bisnis produk turunan madu menguntungkan dan layak untuk dikembangkan.
\end{abstract}

Kata Kunci : nilai tambah, marjin, madu, Hayami, $R / C$

\section{ABSTRACT}

The purposes of this study are: 1) to determine the ratio of added values, productivities, and distribution margins resulting from any derived products of honey, and 2) to determine the efficiency of derived products of honey during the period of analysis from 2012 until 2013. The research was carried out in the $C V$. Madu Apiari Mutiara located in Depok, West Java. The hayami method, the productivity ratio and the $R / C$ ratio were employed to analyze the data. Results from data analyses showed that the average value added per production of the whole product is Rp 20,892.90, - or the value added ratio $35.65 \%$ on an average. The product with the highest productivity of all is honey shampoo. Overall, the $R / C$ value on an average amounted to 1.90 that means business efficiency of derived products of honey is profitable and feasible to be developed.

Keywords: added value, margin, honey, Hayami, $R / C$. 


\section{PENDAHULUAN}

CV. Madu Apiari Mutiara merupakan perusahaan yang memproduksi produk turunan madu tepatnya di daerah Cimanggis Depok, Jawa Barat. Perusahaan ini juga tercatat sebagai salah satu binaan LPPM Institut Pertanian Bogor (IPB). Madu yang dibuat sudah dapat dikatakan berstandar nasional (SNI) dan sesuai standar industri farmasi saat ini karena mampu memenuhi syarat uji dengan kadar air minimum yaitu 18-19 \% dengan menggunakan alat dehumudyfyer, dimana beberapa produsen madu yang ada belum mampu melakukannya saat ini.

Produk turunan madu yang diproduksi CV. Madu Apiari Mutiara termasuk kedalam kategori produk turunan madu farmasi dan kosmetika yaitu antara lain sabun madu, sampo madu, cream madu dan madu tetes mata. Beberapa produk turunan madu kosmetika yang ada (sabun, sampo dan cream) sangat diminati konsumen dan memiliki tingkat penjualan cukup baik, namun perusahaan ini masih terbilang baru dalam menghasilkan produk turunan madu saat ini. Pemasaran produk-produk turunan madu yang ada tidak hanya untuk kalangan konsumen rumah tangga, melainkan sudah dipasarkan untuk konsumen retailindustri melalui supermarket-supermarket organik salah satu diantaranya adalah Serambi Botani yang merupakan toko dan cafe dalam mengutamakan kualitas produk yang baik bagi kesehatan dengan memenuhi standar healthy life style dan healthy café.

Penerapan nilai tambah pada produk turunan madu pada CV. Madu Apiari Mutiara diharapkan dapat memberikan kontribusi nyata dalam hal pendapatan dan menjadi suatu tolak ukur untuk meningkatkan nilai tambah produk turunan madu dalam rangka meningkatkan dan mengembangkan usahanya. Berdasarkan permasalahan tersebut, maka perlu dilakukan penelitian dengan judul "Analisis Nilai Tambah Produk Turunan Madu Pada CV. Madu Apiari Mutiara Cimanggis Depok, Jawa Barat".

\section{METODE PENELITIAN}

\section{Lokasi dan Waktu Penelitian}

Penelitian dilaksanakan di CV. Madu Apiari Mutiara yang beralamat di Jalan Putri Tunggal Komplek Casa Coronza No 102 Kelurahan Harjamukti, Kecamatan Cimanggis Depok, Jawa Barat. Penentuan lokasi penelitian dilakukan secara sengaja (purposive) oleh penulis berdasarkan pertimbangan bahwa perusahaan tersebut merupakan perusahaan madu yang telah tersertifikasi (SNI) dan merupakan satusatunya perusahaan yang melakukan diversifikasi produk turunan madu diantara perusahaan lain di wilayah sama, tepatnya di Kecamatan Cimanggis. Penelitian ini dilaksanakan pada Bulan Desember 2014 hingga Mei 2015.

\section{Jenis dan Sumber Data}

Jenis data yang digunakan dalam penelitian ini adalah kuantitatif yang terdiri dari data primer dan data sekunder. Data primer diperoleh secara langsung dilapangan melalui teknik wawancara mendalam (in depth interview) dengan bantuan daftar pertanyaan, sedangkan data sekunder diperoleh melalui jurnal dan sumber terkait yang relevan bagi penelitian. Sumber data primer diperoleh dari wawancara dengan pemilik CV. Madu Apiari Mutiara yaitu bapak Ir. Sri Hidayat serta karyawan produksi yang didukung dengan beberapa catatan perusahaan, sedangkan sumber data sekunder diperoleh dari data BPS, Dinas Pertanian, jurnal serta publikasi terkait.

\section{Metode Pengumpulan Data}


Peneliti melakukan pengumpulan datadata yang diperlukan selama penelitian berlangsung dengan beberapa cara yaitu :

1. Observasi

Observasi adalah metode pengumpulan data yang tidak hanya terbatas pada orang tetapi juga objek-objek alam yang lain (Sugiyono, 2012 :202). Dalam penelitian ini, peneliti melakukan observasi secara langsung yang berkenaan dengan aktivitas-aktivitas yang berkenaan dengan objek yang diteliti.

\section{Wawancara}

Wawancara dilakukan dengan melaksanakan tanya jawab secara langsung kepada pemilik dan karyawan setempat guna memperoleh gambaran dan informasi secara umum dengan terperinci terhadap data-data yang dibutuhkan oleh peneliti. Dalam pelaksanaan wawancara, responden dalam hal ini tidak diberikan kuesioner yang harus diisi, peneliti hanya mencatat secara tertulis dari hasil pertanyaan yang diajukan yang disebut dengan wawancara berstruktur.

\section{Metode Analisis Data}

Analisis data yang digunakan dalam penelitian ini yaitu analisis nilai tambah, produktivitas dan analisis $\mathrm{R} / \mathrm{C}$ ratio. Periode analisis data yang dilakukan yaitu selama dua tahun. Analisis nilai tambah yang digunakan adalah metode Hayami. Analisis ini digunakan untuk menghitung persentase nilai tambah setiap produk turunan madu, nilai output, keuntungan, imbalan tenaga kerja, serta marjin yang dihasilkan. Sedangkan analisis rasio penerimaan atas biaya dilakukan untuk mengetahui persentase efisiensi usaha setiap produk turunan madu selama periode analisis yaitu dengan perhitungan $\mathrm{R} / \mathrm{C}$ ratio. Perhitungan metode ini menggunakan alat bantu software computer Ms. Excel 2010.

\section{Analisis Nilai Tambah}

Analisis nilai tambah pengolahan dilakukan pada subsistem produksi sampai pengemasan yang tujuannya untuk menentukan besarnya nilai tambah akibat dari suatu proses pengolahan madu murni menjadi produk turunan madu. Nilai tambah tersebut diperoleh dari selisih nilai output dengan harga bahan baku dan nilai sumbangan input lain per kilogram. Nilai tambah ini merupakan nilai tambah kotor karena masih mengandung bagian untuk pendapatan tenaga kerja langsung.

Sumber-sumber dari nilai tambah tersebut adalah dari pemanfaatan faktorfaktor produksi perusahaan, seperti tenaga kerja, modal, sumber daya, dan manajemen. Langkah-langkah yang harus dilakukan dalam menganalisis nilai tambah, yaitu : (1) membuat arus komoditas, mengidentifikasi setiap transaksi yang terjadi (3) memilih dasar perhitungan. Adapun metode nilai tambah pengolahan yang digunakan dalam penelitian ini adalah analisis nilai tambah dengan metode Hayami, karena dilakukan pada subistem produksi sekunder (olahan).

Analisis nilai tambah metode Hayami menghasilkan keluaran sebagai berikut :

1) Perkiraan nilai tambah dalam rupiah (Rp)

2) Rasio nilai tambah terhadap jumlah produk yang dihasilkan dengan persen

3) Imbalan tenaga kerja dalam persen (\%)

4) Keuntungan perusahaan dalam rupiah (Rp)

5) Tingkat keuntungan perusahaan dalam persen $(\%)$

6) Marjin, menunjukkan kontribusi pemilik faktor produksi selain bahan baku yang digunakan dalam proses produksi.

\section{Rasio-Rasio Nilai Tambah dan Analisis Produktivitas}


Rasio-rasio nilai tambah digunakan untuk mengukur kemajuan yang dicapai dalam produktivitas suatu perusahaan terutama menyangkut nilai tambah produknya. Jika nilai tambah $>50 \%$, maka nilai tambah tergolong tinggi dan sebaliknya jika nilai tambah $<50 \%$, maka nilai tambah tergolong rendah (Sudiyono, 2004). Rasiorasio nilai tambah yang digunakan untuk pengukuran produktivitas antara lain :

a. Rasio nilai tambah per tenaga kerja ( $\mathrm{Rp} /$ Tenaga kerja) Merupakan kunci dari pengukuran produktivitas yang mengukur besarnya nilai tambah untuk setiap satuan penggunaan input tenaga kerja. Rumusnya = Nilai tambah : Jumlah Tenaga kerja (Rata-rata per periode).

Rasio Tinggi :Lebih banyak keuntungan yang dihasilkan dari kemampuan perusahaan dalam menciptakan kekayaan.

RasioRendah : Menunjukkan jumlah tenaga kerja atau prosedur kerja yang kurang menguntungkan.

b. Rasio output per tenaga kerja (Rp/Tenaga kerja) Menunjukkan jumlah output yang mampu dihasilkan oleh setiap tenaga kerja langsung perusahaan. Rumusnya = Output : Jumlah Tenaga kerja (Rata-rata per periode).

Rasio Tinggi : Terjadi efisiensi yang baik dari setiap tenaga kerja.

Rasio Rendah : Terjadi inefisiensi dalam proses produksi.

c. Rasio nilai tambah per nilai output (\%) Menunjukkan pengukuran besarnya nilai tambah untuk setiap kali output yang dihasilkan. Rumusnya $=$ (Nilai Tambah : Nilai Output) x $100 \%$ Rasio Tinggi : Efisiensi yang baik antara biaya produksi dan nilai output.
Rasio Rendah : Inefisiensi biaya produksi.

d. Rasio nilai tambah per biaya tenaga kerjaMencerminkan daya saing suatu perusahaan dalam hal biaya tenaga kerjanya. Rumusnya = Nilai Tambah : Biaya Tenaga Kerja Rasio Tinggi : Daya saing perusahaan tersebut besar dalam hal biaya tenaga kerjanya.

Rasio Rendah : Produktivitas rendah, atau tingkat upah tinggi tetapi tidak sesuai dengan produktivitas yang dihasilkan.

e. Rasio keuntungan per nilai tambah (\%) Menunjukkan rasio keuntungan dari nilai tambah yang diperoleh. Rumusnya $=$ (Keuntungan $:$ Nilai Tambah) x 100\%

Penelitian ini hanya sebatas menganalisis rasio nilai nilai tambah per nilai produk yang disebut dengan rasio nilai tambah. Rasio ini merupakan persentase nilai tambah dari masing-masing produk terhadap output yang mampu dihasilkan.

Penelitian ini hanya sebatas menganalisis rasio nilai nilai tambah per nilai produk yang disebut dengan rasio nilai tambah. Rasio ini merupakan persentase nilai tambah dari masing-masing produk terhadap output yang mampu dihasilkan.

\section{Analisis Rasio Penerimaan Atas Biaya (R/C Ratio) \\ R/C ratio atau Return Cost Ratio} merupakan analisis yang digunakan untuk mengukur biaya suatu produksi. $\mathrm{R} / \mathrm{C}$ adalah perbandingan antara total penerimaan dengan total biaya dan menunjukkan pendapatan kotor (penerimaan) yang diterima untuk setiap $\mathrm{Rp} 100$,- yang dikeluarkan dalam produksi (Soekartawi, 2003 :58). Nilai R/C ratio juga menunjukan efisiensi suatu usaha. $\mathrm{R} / \mathrm{C}$ ratio secara 
matematik hal ini dapat dituliskan sebagai berikut :

$\mathrm{R} / \mathrm{C}=-$

$\mathrm{TR}=\mathrm{P} \times \mathrm{Q}$

$\mathrm{TC}=\mathrm{FC}+\mathrm{VC}$

$\mathrm{R} / \mathrm{C}$ ratio $=$

Dimana :

$\mathrm{TR}=$ Total penerimaan

$\mathrm{TC}=$ Total biaya

$\mathrm{FC}=$ Biaya tetap (fixed cost)

$\mathrm{VC}=$ Biaya variabel $($ variable cost $) \mathrm{P}=$

harga output

$\mathrm{Q}=$ total output

Kriterianya adalah sebagai berikut :

$\mathrm{R} / \mathrm{C}$ ratio $>1$, usaha menguntungkan dan layak dikembangkan $\mathrm{R} / \mathrm{C}$ ratio $<1$, usaha merugikan dan tidak layak dikembangkan $\mathrm{R} / \mathrm{C}$ ratio $=1$, usaha impas tidak untung dan tidak rugi.

\section{HASIL DAN PEMBAHASAN}

\section{Analisis Nilai Tambah}

Analisis nilai tambah pengolahan produk turunan madu CV. Madu Apiari Mutiara dilakukan hanya per proses produksi selama dua tahun periode analisis yaitu tahun 2012 dan 2013 dengan menggunakan metode Hayami. Dasar perhitungan nilai tambah yang digunakan adalah per satuan bahan baku, dalam hal ini menggunakan satuan kilogram $(\mathrm{kg})$. Jenis madu murni yang digunakan hanya dua yaitu madu karet dan madu kapuk randu. Data yang digunakan dalam penelitian ini adalah data sistem produksi yang dilakukan perusahaan mulai dari input sampai dengan output seperti kuantitas bahan baku dan bahan penolong yang digunakan, jumlah waktu dan tenaga kerja setiap kali aktivitas produksi, serta tahapan proses produksi yang dilakukan dari awal hingga akhir dan beberapa data produksi terkait lainnya.

\section{Input dan Output Produk Turunan Madu CV. Madu Apiari Mutiara}

Input dalam hal ini adalah faktorfaktor produksi dan sumber daya lainnya yang digunakan dalam proses produksi untuk menghasilkan produk turunan madu. Input yang dibahas dalam hal ini hanya sebatas input penggunaan bahan baku madu murni, sedangkan output adalah kuantitas hasil produk akhir yang mampu dihasilkan oleh perusahaan. Jumlah input dan output produk turunan madu CV. Madu Apiari Mutiara dalam penelitian ini hanya mencakup dari ketiga produk turunan madu kosmetika yang dihasilkan perusahaan yaitu sabun, sampo, serta cream madu. Hal ini dikarenakan dari ketiga produk inilah yang telah diproduksi perusahaan serta memiliki data terlengkap hingga tahun 2013.

Tentu dengan mengetahui jumlah penggunaan bahan baku maupun hasil produksi dalam perusahaan, tingkat produktivitas, nilai tambah serta efisiensi produk yang dihasilkan dapat diukur dengan baik dan akurat.

\section{Sumbangan Input lain Produk Turunan Madu CV. Madu ApiariMutiara}

Sumbangan input lain adalah input dari pengunaan bahan-bahan lain yang ikut dalam proses pertambahan nilai tersebut selain bahan baku dan tenaga kerja. Sumbangan input lain tersebut terdiri dari bahan bakar, bahan penolong, bahan kemasan serta penyusutan alat yang digunakan dalam proses produksi. Biaya penyusutan tidak dimasukkan dalam penelitian ini dengan alasan bahwa analisis nilai tambah hanya dilakukan per proses produksi, sedangkan penyusutan alat umumnya dihitung dengan satuan periode per bulan atau per tahun produksi. Banyak dan besarnya setiap input lain akan mempengaruhi besarnya nilai tambah produk yang dihasilkan, karena terdapat 
tambahan biaya per input yang dimasukkan dalam perhitungan nilai tambah tersebut. Sumbangan input lain dinyatakan dalam satuan harga $(\mathrm{Rp})$ per input.

Terlihat bahwa penggunaan sumbangan input lain per proses produksi di tahun 2012-2013 untuk pembuatan sabun madu (batangan dan cair) masing- masing sebesar Rp 7.898,31,- per kg dan Rp. 4.545,97,-- per kg, untuk sampo madu Rp 4.614,93,- per $\mathrm{kg}$, dan cream madu sebesar Rp. 4.241,17,- per kg. Penggunaan sumbangan input lain terbesar diperoleh sabun madu sedangkan penggunaan terkecil diperoleh cream madu. Hal ini disebabkan oleh intensitas produksi untuk mengolah sabun madu yang lebih banyak dilakukan dan memiliki hasil output produk yang sifatnya lebih padat, kondisi inilah yang menjadikan produk ini sangat membutuhkan bahan penolong, sedangkan untuk cream madu intensitas produksi yang dilakukan lebih sedikit jika dibandingkan ketiga produk lainnya serta tidak membutuhkan bahan-bahan penolong yang begitu banyak.

\section{Analisis Nilai Tambah Sabun Madu}

Analisis nilai tambah sabun madu dilakukan per proses produksi pada tahun 2012 dan 2013. Produk turunan ini diproduksi dalam dua jenis yang berbeda yaitu sabun madu batangan (padat) dan juga sabun madu cair. Alur proses dan kuantitas produksi dari kedua jenis produk ini pun berbeda satu sama lain. Oleh karena itu perlu dilakukan analisis masing-masing dari kedua jenis produk tersebut agar terlihat lebih jelas persentase perbandingan nilai tambah dan marjin yang mampu dihasilkan.

\section{Analisis Nilai Tambah Sabun Madu batangan}

Sabun madu batangan memiliki harga jual terendah yaitu $\mathrm{Rp} 35.000,-$ per kilogram. Bahan baku yang digunakan adalah madu murni jenis nektar karet dengan kuantitas rata-rata antara 7 sampai dengan 8 kilogram, sementara output yang mampu dihasilkan rata-rata antara 9 sampai dengan 10 kilogram masing- masing per proses produksi. Bentuk output produk ini seperti sabun pada umumnya hanya saja yang membedakan dari segi warna dan ukuran. Warnanya terlihat lebih coklat kehitaman karena pengaruh dari madu tersebut serta bentuk yang sedikit lebih oval dari sabun biasanya.

Nilai tambah terbesar diperoleh di tahun 2013 yaitu Rp 10.241,36,- per kg bahan baku dengan rasio 22,20 \%. Jika dilihat nilai ini lebih tinggi sekitar 2,81\% dari tahun 2012. Nilai tambah tersebut dipengaruhi oleh selisih nilai output dengan harga bahan baku serta sumbangan input lain (bahan bakar, bahan penolong, bahan kemasan) yang berbeda dengan sabun madu cair yaitu texapon,aromatheraphy, minyak kelapa, minyak zaitun, stearict acid, $\mathrm{NaOH}$, gula pasir dan kertas kemasan sabun. Harga bahan baku hanya mengalami kenaikan sebesar $\mathrm{Rp} 1.000,-$ per $\mathrm{kg}$ dan input lain $\mathrm{Rp} 1,04,-$ per $\mathrm{kg}$, sehingga nilai tambah yang diperoleh masih lebih besar dari sebelumnya meskipun tidak ada kenaikan harga output produk di tahun 2013. Hal ini tidak terlepas dari pengaruh angka faktor konversi yang diperoleh melalui pembagian antara output dengan input. Terlihat bahwa angka faktor konversi lebih besar $(0,08)$ di tahun ini, artinya jumlah output maupun nilai output produk yang dihasilkan lebih besar dari sebelumnya. Oleh karena itu dapat dikatakan bahwa semakin besar angka faktor konversi maka akan semakin banyak jumlah output yang mampu dihasilkan dan tentu dapat menambah nilai dari produk tersebut. Terlihat disini bahwa penggunaan bahan baku lebih sedikit namun dapat menghasilkan jumlah output yang lebih banyak di tahun 2013. Hal ini disebabkan adanya instruksi terkait efisiensi produksi 
oleh perusahaan untuk produk ini yaitu dalam hal penghematan bahan baku. Beberapa perlakuan khusus pun dilakukan seperti mencampurkan bahan baku madu murni dari dua jenis yang berbeda namun dengan kuantitas yang sama, serta adanya sedikit pengecilan ukuran produk di tahun ini.

Marjin disini artinya adalah keuntungan rupiah per kilogram yang diperoleh dari selisih nilai output dengan harga bahan baku madu murni yang digunakan. Marjin terbesar diperoleh tahun 2013 yaitu Rp 18.140,71,- per proses produksi dengan distribusi share balas jasa faktor produksi terbesar untuk keuntungan perusahaan $(52,22 \%)$ dan share terkecil untuk pendapatan tenaga kerja $(4,24 \%)$. Hal ini dipengaruhi oleh kenaikan upah harian tenaga kerja langsung sebesar 1,66 $\%$ yaitu menjadi Rp 1.875,- sehingga imbalan tenaga kerja per kilogram yang diperoleh pun ikut meningkat di tahun ini.

Kenaikan upah berlaku untuk semua jenis produk karena menggunakan tenaga kerja yang sama. Faktor ini juga tidak terlepas dari angka koefisien tenaga kerja yang mengalami peningkatan sebesar $2 \%$ di tahun tersebut. Berdasarkan hasil analisis nilai tambah sebelumnya, maka diperoleh nilai tambah rata-rata per proses produksi sabun madu batangan tahun 2012-2013 yaitu sebesar Rp 9.318,66,- per kg bahan baku dengan rasio nilai tambah rata-rata 20,08\%.

\section{Rasio-Rasio Nilai Tambah}

Rasio nilai tambah adalah suatu persentase nilai tambah dari nilai output atau nilai produk tersebut. Rasio nilai tambah dihitung dengan cara membagi langsung nilai tambah dengan nilai output yang dihasilkan dari masing-masing produk, baik melalui perhitungan sendiri (hasil olahan) maupun informasi langsung dari pihak CV. Madu Apiari Mutiara yaitu seperti jumlah output produk, biaya tenaga kerja dan jumlah tenaga kerja. Satuan ukuran yang digunakan dalam perhitungan rasio-rasio ini dinyatakan dalam rupiah (Rp) dan persentase $(\%)$ yang dilakukan dalam sekali proses produksi selama tahun 2012-2013.

Dengan adanya pengukuran rasio nilai tambah ini, tentu dapat terlihat lebih dalam persentase produktivitas serta efisiensi dari setiap produk maupun tenaga kerja dalam menghasilkan nilai tambah. Rasio-rasio pengukuran yang akan dibahas dalam penelitian ini hanya dibatasi pada empat rasio yaitu antara lain : rasio nilai tambah per tenaga kerja, rasio output per tenaga kerja, rasio nilai tambah per nilai output, rasio nilai tambah per biaya tenaga kerja, serta rasio keuntungan per nilai tambah. Rasio nilai tambah tenaga kerja per biaya tenaga kerja tidak di bahas dalam penelitian ini dengan alasan bahwa tenaga kerja yang digunakan serta upah per hari yang diberikan sama jumlahnya untuk setiap produk turunan madu yang dihasilkan.

\section{Rasio-Rasio Nilai Tambah Sabun Madu batangan}

Rasio nilai tambah sabun madu batangan dilakukan untuk mengetahui persentase produktivitas tenaga kerja langsung maupun persentase nilai tambah dari nilai produk ini yang tentu dapat diukur dengan beberapa rasio yang telah disebutkan sebelumnya. Terdapat indikator dari empat jenis rasio yang digunakan yaitu rasio nilai tambah per tenaga kerja untuk mengetahui besarnya nilai tambah sabun madu batangan yang mampu dihasilkan dari setiap tenaga kerja langsung, rasio output per tenaga kerja untuk mengetahui kondisi efisiensi atau inefisiensi dari setiap tenaga kerja langsung yang ada dalam memproduksi sabun madu batangan, rasio nilai tambah per nilai output untuk mengetahui tingkat efisiensi antara biaya produksi dan nilai output dari sabun madu batangan tersebut, serta rasio nilai 
tambah per biaya tenaga kerja untuk mengetahui seberapa besar daya saing yang tenaga kerja dalam menciptakan suatu nilai tambah dari proses produksi sabun madu batangan.

\section{Analisis Nilai Tambah Sabun Madu cair}

Sabun madu cair memiliki bentuk produk yang serupa dengan sampo madu karena memang menggunakan jenis madu yang sama dan sifat produk yang cair. Perbedaanya hanya terlihat tidak terlalu kental untuk produk ini serta memiliki harga jual yang lebih tinggi dari sabun madu batangan yaitu Rp 44.000,- per kilogram. Bahan baku yang digunakan sama seperti sampo dan sabun madu batangan yaitu madu murni jenis karet dengan kuantitas rata-rata antara 8 sampai dengan 9 kilogram, sedangkan output yang dihasilkan rata-rata antara 10 sampai dengan 11 kilogram masing-masing per proses produksi. Nilai tambah terbesar diperoleh di tahun 2013 yaitu $\mathrm{Rp} 23.631,93,-$ per $\mathrm{kg}$ bahan baku dengan rasio nilai tambah 42,06 \%. Jika dilihat nilai ini lebih tinggi sekitar 2,16\% dari tahun 2012. Nilai tambah tersebut dipengaruhi oleh selisih nilai output dengan harga bahan baku serta sumbangan input lain (bahan bakar, bahan penolong, bahan kemasan) yang berbeda dengan sabun madu batangan yaitu minyak kelapa, stearict acid, $\mathrm{NaOH}$, gula pasir dan botol kemasan sabun madu cair. Harga bahan baku hanya mengalami kenaikan sebesar Rp 1.000,- per $\mathrm{kg}$ dan input lain Rp 2,89,- per kg, sehingga nilai tambah yang diperoleh masih lebih besar dari sebelumnya, meskipun terlihat tidak ada kenaikan harga output produk di tahun 2013. Hal ini tentu tidak terlepas dari pengaruh angka faktor konversi yang diperoleh melalui pembagian output dengan input.

Terlihat bahwa faktor konversi lebih besar $(0,09)$ di tahun ini, artinya bahwa kenaikan ini lebih besar satu persen di bandingkan sabun madu batangan dan output yang dihasilkan tentu lebih banyak dari tahun sebelumnya.

Marjin terbesar diperoleh tahun 2013 yaitu Rp 28.180,79,-- per kg, dengan distribusi share balas jasa faktor produksi terbesar untuk keuntungan perusahaan $(81,52 \%)$ sedangkan share terkecil untuk pendapatan tenaga kerja langsung (2,33\%). Berdasarkan hasil analisis nilai tambah sebelumnya, maka diperoleh nilai tambah rata-rata per proses produksi sabun madu cair tahun 2012-2013 yaitu Rp 22.288,60,-/kg bahan baku dengan rasio nilai tambah rata-rata $40,98 \%$.

\section{Rasio-Rasio Nilai Tambah Sabun Madu cair}

Rasio nilai tambah sabun madu cair dilakukan untuk mengetahui persentase produktivitas tenaga kerja langsung maupun persentase nilai tambah dari nilai produk ini yang tentu dapat diukur dengan beberapa rasio yang telah disebutkan sebelumnya. Terdapat indikator dari empat jenis rasio yang digunakan yaitu rasio nilai tambah per tenaga kerja untuk mengetahui besarnya nilai tambah sabun madu cair yang mampu dihasilkan dari setiap tenaga kerja langsung, rasio output per tenaga kerja untuk mengetahui kondisi efisiensi atau inefisiensi dari setiap tenaga kerja langsung yang ada dalam memproduksi sabun madu cair, rasio nilai tambah per nilai output untuk mengetahui tingkat efisiensi antara biaya produksi dan nilai output dari sabun madu cair tersebut, serta rasio nilai tambah per biaya tenaga kerja untuk mengetahui seberapa besar daya saing yang tenaga kerja dalam menciptakan suatu nilai tambah dari proses produksi sabun madu cair.

\section{Analisis Nilai Tambah Sampo Madu}

Sampo madu memiliki bentuk produk yang hampir sama dengan sabun madu cair hanya saja berbeda dari segi kemasan dan 
harga. Produk ini memiliki sifat yang lebih kental jika dibandingkan dengan sabun madu cair, serta harga jualnya yang lebih tinggi yaitu $\mathrm{Rp} 45.000$,- per kilogram. Bahan baku yang digunakan yaitu madu murni jenis karet dengan kuantitas ratarata antara 8 sampai 9 kilogram, sedangkan output yang mampu dihasilkan rata-rata antara 11 sampai 12 kilogram masing-masing per proses produksi

\section{Rasio-Rasio Nilai Tambah Sampo Madu}

1. Rasio Nilai Tambah Per Tenaga Kerja Jumlah kekayaan per kilogram bahan baku yang dapat dihasilkan dari sebuah proses produksi dengan menggunakan jumlah tenaga kerja yang tersedia dapat diukur dengan menggunakan rasio ini. Besarnya rasio terbesar diperoleh di tahun 2013 yaitu Rp 10.575,61,-. Artinya, setiap tenaga kerja langsung mampu meningkatkan nilai tambah sampo madu $\mathrm{Rp} 10.575,61$,per proses produksi di tahun tersebut. Rasio ini terlihat meningkat dari tahun sebelumnya karena nilai tambah yang diperoleh juga mengalami peningkatan menjadi sebesar Rp 31.726,84,- per kg. Selain itu faktor tenaga kerja yang digunakan juga mempengaruhi besarnya rasio yang dihasilkan, karena dengan menggunakan tenaga kerja yang sama, tentu dapat lebih memahami kondisi perusahaan tersebut dan produksi yang dihasilkan dapat tetap optimal.

Berbeda halnya ketika harus menggunakan tenaga kerja yang berbeda yang belum memahami sepenuhnya terkait produksi dan kondisi perusahaan. Rasio yang diperoleh ini tergolong tinggi dari rasio nilai tambah per tenaga kerja minuman madu PUSBANHAS yang hanya memperoleh nilai sebesar $\mathrm{Rp}$ 1.796,03,- dalam satu tahun produksi. Hal ini menunjukkan bahwa faktor keuntungan terhadap kekayaan perusahaan yang dihasilkan dari proses produksi sampo madu mampu melebihi dari minuman madu di PUSBANHAS tersebut.

\section{Rasio Output Per Tenaga Kerja}

Jumlah output produk yang dapat dihasilkan oleh setiap tenaga kerja langsung dapat diukur dengan menggunakan rasio ini. Rasio output per tenaga kerja terbesar diperoleh di tahun 2013 yaitu $4,08 \mathrm{~kg}$. Artinya, setiap tenaga kerja langsung dapat menghasilkan sampo madu sebanyak 4,08 kg per proses produksi di tahun terebut. Hal ini terjadi karena perusahaaan, dalam hal ini yaitu pihak owner selalu memberikan motivasi dan insentif berupa bonus tambahan kepada setiap tenaga kerja langsung untuk selalu maksimal dalam melakukan aktivitas produksi. Kondisi ini didukung juga dengan adanya permintaan yang begitu tinggi di dua tahun tersebut yaitu tahun 2012-2013, sehingga tenaga kerja di tahun ini menjadi lebih produktif, mengingat produk ini merupakan produk dengan permintaan tertinggi diantara ketiga produk lainnya. Hal ini juga tidak terlepas dari adanya kenaikan jumlah output sebesar $12,24 \mathrm{~kg}$. Tenaga kerja langsung yang digunakan pada tahun 2013 sebanyak 3 orang. Rasio yang diperoleh ini tergolong tinggi jika dibandingkan dengan rasio output per tenaga kerja minuman madu PUSBANHAS yang hanya mampu memperoleh nilai sebesar 12.557,03 kg dalam satu tahun produksi.

\section{Rasio Nilai Tambah Per Nilai Output \\ Hasil Persentase nilai tambah yang} dihasilkan dari nilai output atau nilai produk dapat diukur dengan menggunakan rasio ini. Rasio terbesar diperoleh di tahun 2013 yaitu 49,31\%. Hal ini menunjukkan bahwa setiap Rp 100,- dari nilai produk ini mampu 
memperoleh nilai tambah $\mathrm{Rp} 49,31$,- per proses produksi di tahun tersebut. Rasio ini terlihat meningkat dari tahun sebelumnya, hal ini disebabkan oleh adanya kenaikan nilai output produk menjadi sebesar $\mathrm{Rp}$ 64.345,79,- kg di tahun ini, sehingga nilai tambah pun menjadi lebih besar. Hal ini tentu dipengaruhi juga dari kenaikan angka faktor konversi yang menjadi sebesar 1,43, sehingga mempengaruhi hasil nilai tambah akhir yang diperoleh di tahun tersebut. Berdasarkan indikator rasio nilai tambah menurut Sudiyono (2004) maka nilai tambah yang dihasilkan masih tergolong rendah. Namun jika dibandingkan dengan rasio nilai tambah per nilai output minuman madu PUSBANHAS yang hanya mampu memperoleh nilai $18,06 \%$ dalam satu tahun produksi, maka nilai tambah yang dihasilkan sampo madu tergolong tinggi. Hal ini juga menunjukkan bahwa nilai dari sampo madu lebih baik dari minuman madu tersebut.

\section{Rasio nilai tambah per biaya tenaga kerja}

Tingkat daya saing tenaga kerja suatu perusahaan dalam menghasilkan nilai tambah suatu produk dapat diukur dengan menggunakan rasio ini. Rasio yang rendah tentunya mencerminkan daya saing tenaga kerja yang kurang baik, hal ini juga ditentukan oleh besar kecilnya biaya tenaga kerja langsung yang dikeluarkan untuk melaksanakan kegiatan produksi. Rasio nilai tambah per biaya tenaga kerja terbesar diperoleh di tahun 2012 yaitu Rp 26,12,-. Artinya, setiap Rp 100,- dari biaya tenaga kerja langsung yang telah dikeluarkan perusahaan dalam memproduksi sampo madu, mampu menghasilkan nilai tambah Rp 26,12,- per proses produksi di tahun tersebut. Rasio di tahun berikutnya terlihat menurun, hal ini disebabkan adanya kenaikan upah tenaga kerja menjadi $\mathrm{Rp}$ $1.875,-$. Meskipun nilai tambah yang diperoleh mengalami kenaikan, namun besarnya upah sangat mempengaruhi rasio yang dihasilkan.

Rasio yang diperoleh ini tergolong tinggi jika dibandingkan dengan rasio nilai tambah per biaya tenaga kerja minuman madu PUSBANHAS yang hanya mampu memperoleh nilai sebesar Rp 43,69,- dalam satu tahun produksi. Hal ini menunjukkan bahwa struktur upah yang diberikan saat ini sudah cukup memadai untuk memotivasi tenaga kerja langsung dalam memproduksi sampo madu, meskipun produktivitas yang dihasilkan belum sepenuhnya optimal karena masih ada beberapa waktu kerja produktif yang tidak terpakai sepenuhnya dalam memproduksi produk ini.

\section{Rasio Keuntungan Per Nilai Tambah}

Persentase keuntungan dari nilai tambah yang dihasilkan dari suatu produk selama periode analisis dapat diukur dengan menggunakan rasio ini. Persentase keuntungan per nilai tambah terbesar diperoleh di tahun 2012 yaitu 98,64\%. Artinya, setiap Rp 100,- dari nilai tambah sampo madu mampu memperoleh keuntungan $\operatorname{Rp} 98,64,-$ per proses produksi di tahun tersebut. Hal ini disebabkan adanya kenaikan nilai tambah produk ini menjadi sebesar Rp 31.726,84,- per kg. Perkembangan tingkat keuntungan mengalami penurunan dan peningkatan sesuai dengan besarnya nilai tambah yang dihasilkan. Hal ini juga menandakan setiap persentase dari nilai tambah tersebut berarti berpengaruh positif terhadap keuntungan produk ini.

Rasio yang diperoleh ini tergolong tinggi jika dibandingkan rasio keuntungan per nilai tambah minuman madu PUSBANHAS yang hanya mampu memperoleh nilai sebesar 88,39\% dalam satu tahun produksi.

Analisis Nilai Tambah Cream Madu

Cream madu memiliki harga output terbesar diantara ketiga produk lainnya yaitu 
Rp 53.000,- per kg. Produk ini memiliki tingkat kekentalan yang sangat tinggi dibandingkan dengan sampo dan sabun madu cair, serta memiliki kemasan botol yang sedikit berbeda. Bahan baku madu murni yang digunakan berbeda dengan ketiga produk lainnya, yaitu madu jenis kapuk dengan kuantitas rata-rata antara 8 sampai 9 kilogram, sedangkan output yang mampu dihasilkan rata-rata antara 10 sampai 11 kilogram masing-masing per proses produksi.

\section{Rasio-Rasio Nilai Tambah Cream Madu}

Rasio nilai tambah cream madu dilakukan untuk mengetahui persentase produktivitas dari nilai produk ini maupun nilai tambah yang dapat diukur dengan beberapa rasio yang telah disebutkan sebelumnya. Berdasarkan perhitungan masing-masing rasio yang akan dilakukan, terdapat tiga rasio utama yaitu rasio nilai tambah per tenaga kerja untuk mengetahui besarnya nilai tambah cream madu yang dihasilkan dari setiap tenaga kerja langsung, rasio output per tenaga kerja untuk mengetahui kondisi efisiensi atau inefisiensi dari setiap tenaga kerja langsung yang ada, serta rasio nilai tambah per nilai output untuk mengetahui tingkat efisiensi yang baik antara biaya produksi dan nilai output dari cream madu.

\section{Perbandingan Nilai Tambah dan Marjin Produk Turunan Madu CV.Madu Apiari Mutiara}

Nilai tambah terbesar dihasilkan oleh sampo madu yaitu Rp 29.467,91,- per kg bahan baku dengan rasio nilai tambah 48,24 \%. Marjin terbesar yang dihasilkan yaitu Rp 34.082,84,- per $\mathrm{kg}$ bahan baku dengan distribusi share balas jasa faktor produksi terbesar diperoleh pada faktor keuntungan perusahaan $(85,28 \%)$ dan sumbangan input lain $(13,54 \%)$, sedangkan distribusi terkecil diperoleh pada faktor pendapatan tenaga kerja langsung $(1,18 \%)$. Hal ini artinya usahasetiap produk turunan madu yang dilakukan per proses produksi di tahun 2012 secara keseluruhan lebih bersifat padat modal, karena dalam melakukan aktivitas produksi, bagian atau share yang diterima setiap pemasok atau pelaku tataniaga sumbangan input lain tersebut sangat besar, sedangkan bagian atau share yang diterima untuk tenaga kerja sangatlah sedikit. Nilai tambah terbesar dihasilkan sampo madu yaitu $\mathrm{Rp} 31.726,84,-$ per $\mathrm{kg}$ bahan baku dengan rasio nilai tambah 49,31\%. Marjin terbesar yang dihasilkan yaitu $\mathrm{Rp}$ 36.345,79,- per $\mathrm{kg}$ bahan baku dengan distribusi share balas jasa faktor produksi terbesar diperoleh pada faktor keuntungan perusahaan $(85,48 \%)$ dan sumbangan input lain $(12,71 \%)$, sedangkan distribusi terkecil diperoleh pada faktor pendapatan tenaga kerja langsung (1,81\%). Hal ini artinya usaha setiap produk turunan madu yang dilakukan per proses produksi di tahun 2013 secara keseluruhan masih bersifat padat modal, karena dalam melakukan aktivitas produksi bagian atau share yang diterima setiap pemasok atau pelaku tataniaga sumbangan input lain tersebut sangat besar, sedangkan bagian atau share yang diterima tenaga kerja sangatlah sedikit, namun sudah lebih besar dibandingkan dari tahun sebelumnya.

Berdasarkan perbandingan analisis nilai tambah selama dua tahun periode tersebut maka diperoleh hasil keseluruhan sebagai berikut :

Nilai tambah terbesar per proses produksi tahun 2012-2013 mampu dihasilkan oleh sampo madu yaitu masing-masing sebesar Rp 29.467,91,-- per kg bahan baku dan Rp $31.726,84,-$ per $\mathrm{kg}$ bahan baku dengan rasio nilai tambah 48,24\% dan 49,31\% serta marjin yang dihasilkan sebesar Rp 34.082,84,- per kg dan Rp 36.345,79,-- per $\mathrm{kg}$. Usaha produk turunan madu per proses produksi selama periode analisis tersebut 
lebih bersifat padat modal yang terlihat dari persentase share distribusi balas jasa faktor produksi yang lebih besar untuk keuntungan perusahaan dan sumbangan input lain dibandingkan share untuk pendapatan tenaga kerja.

\section{Perbandingan Rasio Nilai Tambah dan Produktivitas ProdukTurunan Madu CV. Madu Apiari Mutiara}

Terlihat bahwa produk yang memiliki persentase terbesar dalam menyumbangkan tingkat produktivitas adalah sampo madu. Hal ini disebabkan oleh nilai output dan nilai tambah yang dihasilkan produk tersebut memang lebih besar jika dibandingkan nilai yang diperoleh produk lainnya, sehingga rasio-rasio yang diperoleh pun ikut mengalami peningkatan. Kondisi ini juga tidak terlepas dari harga bahan baku yang rendah serta penggunaan input lain yang tidak terlalu sebesar produk lain, meskipun harga jual produk ini dapat dikatakan lebih rendah dari salah satu produk yaitu cream madu. Selain faktorfaktor tersebut tentu ada beberapa faktor lainnya yang mempengaruhi, yaitu tingkat permintaan dan penjualan yang selalu tinggi terhadap sampo madu tersebut, sehingga optimalisasi dari setiap tenaga kerja yang ada untuk memproduksi produk ini pun ikut meningkat.

Berdasarkan hasil perbandingan rasio-rasio nilai tambah yang diperoleh produk turunan madu kosmetika CV. Madu Apiari Mutiara dengan produk turunan madu pangan, dalam hal ini adalah minuman madu PUSBANHAS, maka dapat dikatakan bahwa produk turunan madu kosmetika memiliki rasio nilai tambah dan produktivitas yang lebih baik daripada produk turunan madu pangan. Hal ini mengindikasikan juga bahwa nilai tambah yang dihasilkan produk turunan madu kosmetika lebih tinggi daripada produk turunan madu pangan. Artinya, produk turunan madu untuk kosmetika memiliki prospek pengembangan yang lebih potensial ketimbang produk turunan madu pangan.

\section{Analisis Rasio Penerimaan Atas Biaya (R/C Ratio)}

Total penerimaan (nilai produksi) merupakan hasil perkalian dari total output yang diperoleh dengan tingkat harga yang berlaku, sedangkan biaya (pengeluaran) total didefinisikan sebagai nilai masukan yang habis terpakai atau dikeluarkan dalam produksi. Untuk melihat suatu efisiensi usaha, dapat dilihat dari rasio penerimaan dengan biaya (R/C) yang merupakan perbandingan antara penerimaan dengan biaya tunai maupun biaya total. R/C ratio dapat dipergunakan untuk melihat penerimaan yang diperoleh pada setiap satuan biaya yang dikeluarkan dalam aktivitas produksi. Terlihat bahwa nilai $\mathrm{R} / \mathrm{C}$ ratio usaha sabun madu batangan tahun 2012 sebesar 2,21. Artinya, setiap tambahan biaya $\mathrm{Rp} 1.000$,- yang dikeluarkan untuk produk tersebut di tahun ini, akan memperoleh penerimaan sebesar $\mathrm{Rp} 2.210$,-. Kemudian nilai R/C tahun 2013 sebesar 2,64 yang menandakan bahwa terdapat penerimaan lebih besar Rp 430,- di tahun ini. Nilai rata-rata $\mathrm{R} / \mathrm{C}$ Ratio selama dua tahun periode analisis diperoleh hasil 2,42 yang artinya produk ini sudah menguntungkan dan efisien dilaksanakan selama tahun 2012-2013 karena angka tersebut menunjukkan lebih besar dari satu (>1). Terlihat bahwa nilai $\mathrm{R} / \mathrm{C}$ - ratio usaha sabun madu cair tahun 2012 sebesar 1,73. Artinya, setiap tambahan biaya Rp 1.000,yang dikeluarkan di tahun ini akan memperoleh penerimaan sebesar Rp 1.730,-Kemudian nilai R/C pada tahun 2013 sebesar 2,20 artinya, tambahan penerimaan yang diperoleh lebih besar Rp 470,- di tahun ini. Nilai rata- rata $\mathrm{R} / \mathrm{C}$ Ratio selama dua tahun periode analisis diperoleh hasil sebesar 1,96. Terlihat bahwa nilai R/C - 
ratio usaha sampo madu tahun 2012 sebesar 1,96. Artinya, setiap tambahan biaya $\mathrm{Rp}$ 1.000,- yang dikeluarkan untuk produk tersebut di tahun ini akan memperoleh penerimaan sebesar Rp 1.960,-. Kemudian nilai $\mathrm{R} / \mathrm{C}$ pada tahun 2013 sebesar 1,70 artinya, tambahan penerimaan di tahun ini lebih sedikit $\mathrm{Rp} 260,-$ dari tahun sebelumnya. Nilai rata-rata $\mathrm{R} / \mathrm{C}$ Ratio selama dua tahun periode analisis diperoleh hasil 1,83. Artinya, usaha produk ini sudah menguntungkan dan efisien dilaksanakan selama tahun 2012-2013. Oleh karena itu, dapat dikatakan usaha sampo madu lebih efisien dibandingkan sabun madu cair, namun tidak lebih efisien dari usaha sabun madu batangan.

\section{KESIMPULAN DAN SARAN}

\section{Kesimpulan}

Berdasarkan hasil pembahasan pada bab sebelumnya, maka penulis dapat menarik kesimpulan sebagai berikut :

a) Produk dengan nilai tambah terbesar selama dua tahun periode analisis dihasilkan sampo madu yaitu masingmasing sebesar Rp 29.467,91,- per kg bahan baku dan Rp 31.726,84,- per kg bahan baku dengan rasio nilai tambah 48,24\% dan 49,31\%. Marjin terbesar yang dihasilkan yaitu Rp 34.082,84,dan Rp 36.345,79,- per kg bahan baku. Nilai tambah rata-rata per proses produksi dari keseluruhan produk selama periode analisis tahun 20122013 yaitu sebesar Rp 20.892,90,- per $\mathrm{kg}$ bahan baku dengan rasio nilai tambah rata-rata $35,65 \%$. Usaha keseluruhan yang dijalankan lebih bersifat padat modal, hal ini terlihat berdasarkan persentase share distribusi yang lebih besar untuk faktor keuntungan perusahaan dan sumbangan input lain daripada share untuk faktor pendapatan tenaga kerja.

b) Produk dengan tingkat produktivitas terbesar dihasilkan sampo madu dengan nilai rata-rata per proses produksi tahun 2012-2013 untuk rasio nilai tambah per tenaga kerja sebesar $\mathrm{Rp}$ 20.398,24,- ; rasio output per tenaga kerja sebesar 7,9 kg ; rasio nilai tambah per nilai output sebesar 97,55\%, ; rasio nilai tambah per biaya tenaga kerja sebesar Rp 43,04,- ; serta rasio keuntungan per nilai tambah sebesar $98,28 \%$.

c) Nilai $\mathrm{R} / \mathrm{C}$ rata-rata keseluruhan produk turunan madu CV. Madu Apiari Mutiara tahun 2012 adalah 1,84, sedangkan nilai $\mathrm{R} / \mathrm{C}$ rata-rata tahun 2013 adalah 1,96 dengan efisiensi terbesar dihasilkan usaha sabun madu batangan yang memperoleh nilai $\mathrm{R} / \mathrm{C}$ rata-rata 2,42 . Jika digabungkan total nilai $\mathrm{R} / \mathrm{C}$ rata-rata keseluruhan produk selama periode analisis tahun 20122013, maka diperoleh nilai R/C sebesar 1,90. Hal ini artinya efisiensi usaha produk turunan madu secara keseluruhan yang dilakukan selama periode analisis sudah cukup baik dan tetap menguntungkan serta layak untuk terus dikembangkan.

\section{Saran}

Berdasarkan penelitian yang telah dilakukan oleh penulis, maka saran untuk CV. Madu Apiari Mutiara antara lain sebagai berikut :

a) Perusahaan dapat meningkatkan nilai tambah untuk setiap produk turunan madu yang ada saat ini, namun karena sampo madu memiliki nilai tambah dan rasio produktivitas terbesar, sebaiknya lebih diutamakan pengembangan untuk produk ini dengan melalui penelitian selanjutnya. 
b) Perusahaan sebaiknya lebih memperhatikan kembali pada aspek penekanan dalam hal pengeluaran biaya, mengingat persentase kenaikan produktivitas yang diperoleh lebih kecil daripada persentase kenaikan biaya.

\section{DAFTAR PUSTAKA}

Alex dan I Made. 2013. Peluang Pasar Produk Perlebahan. Alih Teknologi Balai Penelitian Teknologi Hasil Hutan Bukan Kayu. Seminar online, (http://www.forda-mof.org/files/, diakses 31 Agustus 2014 pkl.17.15)

Bisnis Agroforestry peluang dan tantangan. http://www.perumperhutani.com diakses 02 September 2014 pkl. 13.00

Daniel, Moehar. 2002. Metode Penelitian Sosial Ekonomi. Jakarta: Bumi Aksara.

HaidarBanna. 2010. "Makalah Madu dan Produk Turunannya". Artikel diakses 26 Desember 2014 pkl. 14.00 dari http://haidarbanna.blogspot.co.id/2012 110/ makalah-aneka-ternaklebah_23.html.

Isdriani, Shinta. 2012. Analisis Nilai Tambah Jahe Merah Instant Pada IRT Enam Putri Jakarta Barat. [Skripsi]. Program Studi Agribisnis. Fakultas Sains Dan Teknologi. Universitas Islam Negeri Syarif Hidayatullah Jakarta.

Kandungan Nutrisi Lebah Madu. http://www.id.wikipedia.org/wiki/Mad u diakses 30 Desember 2014 pkl.16.30

Marimin \& Maghfiroh, Nurul. 2010. Aplikasi Teknik Pengambilan
Keputusan Dalam Manajemen Rantai Pasok. Cetakan Pertama. IPB Press. Bogor.

Nuryati,Sri.2012."Status dan Potensi Madu Organis Nasional dan Internasional".

Siregar, Amalia Afrida. 2012. Analisis Nilai Tambah Pengolahan Salak (Studi

Kasus : Industri Kecil Pengolah Buah Salak Agrina, Desa Persalakan, Kecamatan Angkola Barat, Kabupaten Tapanuli Selatan). [Skripsi]. Program Studi Agribisnis. Fakultas Pertanian. Universitas Medan Sumatera Utara.

Soekartawi. 2003. Agribinis Teori dan Aplikasinya. Jakarta : PT Raja Grafindo Persada.

Subiantoro, Sigit. 1995. Pengukuran dan Analisa Produktivitas dengan Metode Nilai Tambah yang Mengarah Pada Sistem Pendukung Keputusan di PT X. [Tesis]. Program Studi Teknik Mesin. Fakultas Manajemen Industri. Universitas Indonesia. Jakarta.

Sugiyono. 2012. Metode Penelitian Bisnis. Bandung : Alfabeta.

Suranto, Adji. 2004. Khasiat dan Manfaat Madu Herbal. Jakarta : Agromedia Pustaka.

Standarisasi Nasional Madu Murni. 2004. http:// www.bsn.or.id/SNI/madu.cpm. diakses 15 Desember 2014 pkl. 08.00

Syamsudin, Lukman. 2001. Manajemen Keuangan Perusahaan : Konsep aplikasidalam Perencanaan, Pengawasan, dan Pengambilan Keputusan. Jakarta : PT. Raja Grafindo Persada. 
* Alamat korespondensi:

eny.dwiningsih@uinjkt.ac.id 